\title{
Safe Collateral, Arm's-Length Credit: Evidence from the Commercial Real Estate Market
}

\author{
Lamont Black \\ DePaul University \\ John Krainer \\ Federal Reserve Bank of San Francisco \\ Joseph Nichols \\ Federal Reserve Board of Governors
}

September 2017

Working Paper 2017-19

http://www.frbsf.org/economic-research/publications/working-papers/2017/19

\section{Suggested citation:}

Black, Lamont, John Krainer, Joseph Nichols. 2017. “Safe Collateral, Arm’s-Length Credit: Evidence from the Commercial Real Estate Market” Federal Reserve Bank of San Francisco Working Paper 2017-19. https://doi.org/10.24148/wp2017-19

The views in this paper are solely the responsibility of the authors and should not be interpreted as reflecting the views of the Federal Reserve Bank of San Francisco or the Board of Governors of the Federal Reserve System. 


\title{
Safe Collateral, Arm's-Length Credit: \\ Evidence from the Commercial Real Estate Market*
}

\author{
Lamont Black L John Krainer $^{\ddagger} \quad$ Joseph Nichols ${ }^{\S}$
}

September 7, 2017

\begin{abstract}
There are two main creditors in commercial real estate: arm's-length investors and banks. We model commercial mortgage-backed securities (CMBS) as the less informed source of credit. In equilibrium, these investors fund properties with a low probability of distress and banks fund properties that may require renegotiation. We test the model using the 2007-2009 collapse of the CMBS market as a natural experiment, when banks funded both collateral types. Our results show that properties likely to have been securitized were less likely to default or be renegotiated, consistent with the model. This suggests that securitization in this market funds safe collateral.
\end{abstract}

JEL Classifications: G21, G23, G32, R33

Keywords: banks, collateral, securitization, commercial real estate

${ }^{*}$ We thank Ata Can Bertay (discussant), Robert DeYoung, Maaike Diepsraten (discussant), Fred Furlong, Kathleen Johnson, and participants at the University of Kansas, Federal Reserve Bank of Boston, University of Richmond, Federal Reserve Bank of Kansas City, Federal Reserve Bank of San Francisco, Financial Management Association 2016, and IBEFA Summer Meetings 2016 for helpful comments. We thank Andy Law and Spencer Perry for assistance in preparing the charts. We thank Anita Todd for editorial assistance. The views expressed are those of the authors and not necessarily those of the Federal Reserve System.

${ }^{\dagger}$ DePaul University, Chicago, IL 60604, tel.: 312-362-5617, lblack6@depaul.edu

${ }^{\ddagger}$ Federal Reserve Bank of San Francisco, San Francisco, CA 94105, tel.: 415.793.2875, john.krainer@sf.frb.org

${ }^{\S}$ Federal Reserve Board of Governors, Washington, DC 20551, tel.: 202-452-2983, joseph.b.nichols@frb.gov 


\section{Introduction}

What types of collateral are best suited to different types of creditors? In corporate finance, firms offer financial contracts to investors and choose among sources of funding. Typically, debt structure is modeled as a trade-off between public debt (e.g., issuing bonds) and bank debt. In this case, only firms that benefit from monitoring will borrow from a bank (Diamond 1991). Empirical evidence has supported this perspective of banks as informed creditors (James 1987). In contrast, bond investors are arm's-length creditors that do not condition covenants and liquidation on costly monitoring. This distinction can be characterized as direct versus indirect finance, with banks functioning as financial intermediaries.

Collateral is a key feature of many debt contracts (i.e., secured debt). Under a debt contract, the borrower makes a fixed payment but occasionally is in default. When a payment is missed and the borrower defaults on a debt contract, a secured creditor has the right to take possession of the debtor's encumbered assets. ${ }^{1}$ Hart and Moore (1998) show that this is a critical component in solving the agency problem in debt finance. Although cash from a project can be fully diverted, the borrower cannot steal the assets underlying the project. The threat of creditor control over these assets implies that the borrower will repay the debt whenever the project delivers sufficient return. In Boot and Thakor (1994), new borrowers can only access credit by issuing secured debt at a high interest rate.

The source of debt funding becomes most relevant in the event of financial distress. Following default, secured creditors must decide whether to liquidate or renegotiate. Liquidation is the discontinuation of operations and sale of the project assets, whereas renegotiation is an alteration of

\footnotetext{
${ }^{1}$ Collateral value is closely reflected in debt contracting. Benmelech, Garmaise, and Moskowitz (2005) examine the asset liquidation values of commercial real estate collateral and find that zoning flexibility leads to a loosening of bank loan underwriting terms. Similarly, Cerqueiro, Ongena, and Roszbach (2016) study a Swedish legal reform reducing collateral value and find that it leads to a tightening of underwriting terms.
} 
the contract terms that allows the project to continue. This decision hinges on the available information and the creditor incentives. ${ }^{2}$ Some creditors are better informed about the creditworthiness of the borrower, which is often a function of who owns the debt. Inefficient liquidation occurs when the continuation value exceeds the liquidation value but the creditor ends the project. This can occur in equilibrium, because project managers cannot credibly commit to future payments. Rajan and Winton (1995) show that more informed creditors make more efficient liquidation and renegotiation decisions. Arm's-length creditors are typically less informed than lenders that have repeated interaction with a borrower. This amplifies financing frictions and makes it very difficult for arm's-length creditors to make efficient liquidation decisions in the event of financial distress.

Commercial real estate is an ideal setting to study different funding sources for secured debt. Prior to the early 2000s, most commercial real estate (CRE) was financed with loans from banks and other types of financial intermediaries. These institutions originated the loans with collateral liens on the properties and held the loans in portfolio. The innovation of commercial mortgage-backed securities (CMBS) in the 1990s provided a growing alternative to portfolio loans from banks or insurance companies, similar to the corporate bond market. This has given owners of large commercial properties a choice between public debt and bank debt in their source of funding. In addition, commercial real estate is one of the largest markets for secured debt. Around the world, real estate is a valuable form of collateral because it is an "immovable" asset (Calomiris, Larrain, Liberti, and Sturgess 2017). ${ }^{3}$

${ }^{2}$ Optimal debt contracts cannot be contingent on ex post information if the borrower's circumstances are not verifiable by outside parties; otherwise, the borrower can falsely pretend to have suffered an adverse shock (Arrow 1974). However, if the borrower's circumstances are observable to the lender, ex post renegotiation allows outcomes contingent on financial distress (Hart and Moore 1998). For instance, loans can be restructured in response to declines in collateral value, even when the lender does not take the collateral.

${ }^{3}$ Immovable asset is known also as "fixed asset" (Berger and Udell 2006). The borrower can sell a fixed asset only by transfer of title, which can occur only if the lender releases the lien. Creditors in emerging markets are often reluctant to lend against movable collateral (such as machinery, accounts receivable, and inventory). 
Commercial real estate loans performed very differently in the crisis depending on their funding source, as can be seen in Figure 1. Delinquencies on loans funded by banks rose gradually, whereas delinquencies on loans funded by CMBS spiked. This figure motivates our analysis, as we want to explore the increase in CMBS delinquencies relative to those on CRE loans at banks. Does the spike in CMBS loan delinquencies reflect differences in the quality of the loans between the two markets or differences in how distressed loans are handled between the markets?

In this paper, we develop and test a simple model of collateral and creditors. Commercial real estate finance differs significantly from the residential mortgage market. This is largely because the contracting mechanisms are different. Like the residential mortgage market, commercial real estate loans can be bundled into pools, which are then used as the collateral backing the issuance of fixed-income securities. ${ }^{4}$ However, in residential real estate, the borrower does not choose the source of funding. Banks decide ex-post whether to securitize residential loans and the borrower has no influence on this decision. Therefore, residential lenders cannot commit to monitoring and this leads to the adverse incentives associated with the subprime residential crisis. This is not the case in the commercial mortgage market where borrowers choose between two distinct funding channels. In this way, commercial real estate finance is more of a corporate market than a consumer market. In our model, the property owner chooses the source of funding based on the riskiness of the project and the likelihood that renegotiation will be required. Banks have a comparative advantage in renegotiation relative to relative the arm's-length CMBS investors, which results in riskier loans being held in bank portfolios. This produces a separating equilibrium in which safer projects are funded in the CMBS market at lower interest rates and riskier projects are funded by banks at higher interest rates. The model implies a market segmentation in commercial real estate loans,

${ }^{4}$ Our focus on renegotiation is related to the residential mortgage papers of Piskorski, Seru, and Vig (2010) and Agarwal, Amromin, Ben-David, Chomsisengphet, and Evanoff (2011). 
with two key empirical predictions. First, loans in bank portfolios will have a higher probability of being in financial distress than observably similar securitized loans. Second, loans in bank portfolios will be renegotiated more often than observably similar securitized loans. To test the model, we use newly available loan-level data from the U.S. bank stress tests. These data allow us to compare commercial real estate loans financed in the capital market with loans financed by banks. Most importantly, the bank stress tests created a window into the loans held by large commercial banks. This data is merged to the Morningstar data on the loans in CMBS pools based on the same set of originators. With these two data sources, we can compare the two funding sources.

The primary challenge in testing these empirical predictions is the simultaneity between funding choice and the negotiation of underwriting terms. This endogeneity can potentially hide the true nature of the sorting taking place in loan markets. For example, consider two properties differing in their default risk. In a world without informational frictions, we would expect both properties to receive funding and both loans to have the same risk-adjusted expected returns. This could be accomplished through some combination of loan pricing and adjustments to the underwriting terms. The probability of future distress and the potential renegotiation to mitigate that distress will inform pricing and underwriting. So long as we observe both loan rates and all the relevant underwriting terms, we can accurately assess the differences in risk between these two hypothetical loans. However, the empirical problem, common to much of the corporate finance and banking literature, is that we do not observe all the relevant underwriting terms. In this paper, we highlight the implicit promise to renegotiate loan terms in response to financial distress (i.e., implication (3) from above). ${ }^{5}$ These implicit features of the loan contract are generally unobservable. Indeed, as we model in the paper, it is likely that borrower demand for renegotiation $\overline{5}$ Black, Krainer, and Nichols $(2017)$ explore the extent to which this unobserved renegotiation option is priced into the loan at origination. 
services is private information and, at least partially, unobservable to the creditor as well.

We address the endogeneity problem by using the shutdown of the CMBS market during the financial crisis as a natural experiment. ${ }^{6}$ From 2007 to 2009, there was no new issuance of CMBS as originators were unable to hedge the risks associated with the warehousing of the loans for securitization. The collapse in the CMBS market came abruptly, as can be seen in Figure 2. Further, the shock roiling all financial markets at that time was systemic and arguably did not originate in the CRE market. However, securitized loans were maturing over this period and needed to be refinanced. With CMBS no longer an option, property owners were forced to turn to banks and alternate sources of financing, including insurance companies and REITs. Thus, after the collapse of CMBS, we are able to observe side-by-side in the banks' portfolios both the traditional bank loans and as well as loans that would normally be securitized. In effect, the 2007 collapse in the CMBS market serves as a natural experiment that allows us to observe the true nature of collateral-based sorting in the commercial real estate market.

Our empirical analysis uses this natural experiment by comparing the performance of different collateral types when funded by a single creditor type. During the CMBS shutdown, banks financed traditional properties as well as properties that would have been financed in the CMBS market. We can compare these two types of loans in our data both in terms of default and renegotiation as a clean test of collateral type without the segmentation of creditor type. To make this comparison, we develop several indicators for loans that would have been securitized. Our first and most basic indicator is whether the loan has a fixed interest rate. Prior to the shutdown, 99\% of loans funded in the CMBS market had a fixed interest rate, consistent with the preferences

\footnotetext{
${ }^{6}$ In the U.S., the CMBS market shutdown was an exogenous shock to a funding channel. Gan (2007) examines the collapse of Japanese land values in the early 1990s as an exogenous shock to collateral values.
} 
of fixed-income investors. ${ }^{7}$ Our use of the fixed-rate mortgage (FRM) and the illiquidity of the private securitization market is similar to the approach of Fuster and Vickery (2014). Expanding on this, we also estimate the probability of securitization using a combined data sample of CMBS and bank loans originated prior to 2007. This allows us to calculate the out-of-sample probabilities of securitization for bank loans during the CMBS shutdown. We then show that these indicators of CMBS similarity for new bank loans originated during the shutdown are negatively correlated with both default and extension. Thus, properties normally funded by arm's length finance, but "counterfactually" funded by the banks, are shown to be safer and less likely to experience any financial distress. Lastly, as a robustness test, we match specific CMBS loans that resolved during the CMBS shutdown with specific bank loans originated shortly thereafter. Using this matching approach yields weaker results statistically, but is still supportive of our hypotheses. CMBS loans that matured and are identified as reappearing on bank balance sheets in a refinancing are found to be safer and less likely to need renegotiation going forward.

The findings in our paper have a number of implications for the future development of secured debt markets. Traditionally, collateral liens were owned and managed by loan originators. However, financial innovations in credit markets have gradually unbundled the process of loan origination and collateral management. Asset-backed securitization is an example of an innovation that allows physical collateral to be funded by arm's-length investors. We document that the ability to fund commercial assets with dispersed creditors has resulted in a market segmentation very similar to corporate debt. In Bolton and Scharfstein (1996), firms with high credit quality issue public debt and firms with low credit quality issue bank debt, which is closely paralleled by our hypotheses for CMBS and bank loans in the commercial real estate market. ${ }^{8}$ In other words,

\footnotetext{
${ }^{7}$ In contrast, less than $30 \%$ of loans funded by banks were fixed-rate loans prior to the CMBS shutdown (Table 1).
}

${ }^{8}$ Debt ownership structure matters to borrowers because coordination problems make agreement difficult among 
safe collateral tends to be funded by arm's-length credit. This helps explain why CMBS deals use renegotiation-proof contracts (pooling and servicing agreements) that prevent loan alterations rather than the transfer of collateral in the event of distress, as was seen in the financial crisis. ${ }^{9}$ Lastly, our focus on commercial real estate builds on Ghent and Valkanov (2016) and Downs and Xu (2015), who examine the differences in portfolio and securitized loans for commercial properties. We believe that this growing area of research will continue to clarify the dual role of financial intermediation and securitization in the evolution of collateral and credit.

The remainder of the paper is organized as follows. Section 2 presents our theoretical model of commercial real estate collateral and creditors. Section 3 describes the data used in the analysis. Section 4 explains the use of the CMBS market shutdown for identification. Sections 5 and 6 present the methodology and results of our two empirical approaches. Section 7 concludes.

\section{A model of collateral and creditors}

This section describes our basic theoretical model where property owners enter the debt market seeking financing for a commercial real estate property. The property can be used as collateral for financing in a CMBS deal or by a bank. The key difference between investors and banks is their ability to evaluate properties in distress. ${ }^{10}$ We develop the model in this setting to focus on efficient liquidation rather than the monitoring of an investment decision. The structure of the model is most similar to the Chemmanur and Fulghieri (1994) corporate model of issuing public debt (bonds) or bank debt (loans).

dispersed creditors when attempting to renegotiate. While borrowing from multiple creditors reduces strategic defaults, it also reduces efficiency when the firm defaults due to liquidity problems.

${ }^{9}$ Securitization separates cash-flow rights and control rights. A strengthening of creditor rights in the securitization market will affect the debt structure decision of corporations, as documented in India following securitization reform (Vig 2013).

${ }^{10}$ Banks do not have an information advantage at origination, so there is no screening of prospective clients. 
There are two types of properties (i.e., fixed asset) that differ in their probability of positive cash flow. Safe properties $(S)$ yield positive cash flow $x$ with probability $p_{S}$ and risky properties $(U$ for unsafe) yield this cash flow with probability $p_{U}$, where $p_{S}>p_{U}$. Otherwise, cash flow is zero. Property type is known only to the property owner but creditors know the share of safe properties, $\phi$. Financial distress occurs when a property fails to yield positive cash flow. In this way, safe properties have a lower likelihood of entering financial distress than risky properties.

The property owner requires external financing in the form of secured debt, with the property serving as collateral (as in Hart and Moore (1998)). When a property becomes distressed, the owner defaults on the debt and the creditor has the right to liquidate the property. Liquidation value of any property is $y$. However, a fraction $\delta$ of the properties will still yield cash flow $x$ if not liquidated, independent of property type. ${ }^{11}$ A property can be evaluated by the creditor to determine whether to extend the debt. If the distressed property is not liquidated and yields positive cash flow, the creditor receives a fraction $k$ of the cash flow, where $k x>y$.

External financing is available either in the CMBS market (i.e., bond market) or from a bank. These two sources of financing differ in their ability to accurately assess the quality of a distressed property. Investors in the CMBS market accurately determine property quality with probability $q$, which is a function of evaluation $\operatorname{costs} c$. Therefore, these investors maximize profit in the distressed state $(\pi)$ by choosing the evaluation cost, as shown in the following equation:

$$
\max _{c} \pi=\delta[q k x+(1-q) y]+(1-\delta)[q y]-c .
$$

The parameter $\delta$ is the proportion of properties that still yield cash flow after distress and $q$ is the probability of investors accurately identifying these properties, where $q$ is increasing in $c .^{12}$

\footnotetext{
${ }^{11}$ Other distressed properties will yield no cash flow even if renegotiated.

${ }^{12}$ Investors' evaluation function $q(c)$ is concave in $c$, such that there are diminishing returns to evaluation costs.
} 
Among the properties that yield cash flow, investors accurately renegotiate with probability $q$ and inaccurately liquidate with probability $(1-q)$. For properties that will not yield cash flow, $(1-\delta)$, there are returns from accurately liquidating, but no returns from inaccurately renegotiating. This is the core of the model highlighting efficient and inefficient liquidation.

In contrast to CMBS investors, banks' probability of accurately determining the quality of a distressed property is $\bar{q}$, where $\bar{q}>q(c)$. This assumption is based on the premise that banks have a comparative advantage in evaluating and renegotiating a distressed property. ${ }^{13}$ This advantage could be due to greater information or flexibility as a single creditor. Banks make a fixed amount of profit in the distressed property state, $\bar{\pi}$, and the amount of this profit exceeds the profit of investors. $^{14}$

Investors and banks determine their required interest rate to maximize total expected profit (П). Investors first decide what evaluation cost they will bear in the event of distress and then decide what interest rate $\left(R^{I}\right)$ to charge. Banks only decide what interest rate $\left(R^{B}\right)$ to charge.

$$
\begin{aligned}
& \max _{R^{I}} \Pi^{I}=p^{I} R^{I}+\left(1-p^{I}\right) \pi^{*}-1 . \\
& \max _{R^{B}} \Pi^{B}=p^{B} R^{B}+\left(1-p^{B}\right) \bar{\pi}-1
\end{aligned}
$$

Total expected profit for CMBS investors and banks is a combination of interest earned on nondistressed properties and profits from distressed properties. ${ }^{15}$ The probabilities of successful repayment for their borrowers $\left(p^{I}\right.$ and $\left.p^{B}\right)$ are determined in equilibrium. The repayment outcomes depend on which types of owners finance their property in the CMBS market or by a bank.

\footnotetext{
${ }^{13}$ We assume that banks can evaluate firms costlessly in the event of distress. This is an extreme assumption, but it simplifies the solution and does not alter the intuition.

${ }^{14}$ Bank profit is greater due to a larger $q$ and a $c$ of zero. In this way, banks extract rents from their borrowers, similar to (Rajan 1992).

${ }^{15}$ The investment of one dollar is a normalization.
} 
Property owners choose their source of financing based on the greatest payoff. The payoffs are a function of the interest rates offered as well as the probability of repayment, $p \in\left(p_{S}, p_{U}\right)$. This can be seen in the owner's expected payoff with financing by investors $\left(J^{I}\left(R^{I}, p\right)\right)$ and the owner's expected payoff with financing by a bank $\left(J^{B}\left(R^{B}, p\right)\right)$ :

$$
\begin{gathered}
J^{I}\left(R^{I}, p\right)=p\left(x-R^{I}\right)+(1-p) \delta q(c)(1-k) x \\
J^{B}\left(R^{B}, p\right)=p\left(x-R^{B}\right)+(1-p) \delta \bar{q}(1-k) x
\end{gathered}
$$

The payoff to property owners is a combination of excess cash flow in the non-distressed state and the probability of positive cash flow in the distressed state. ${ }^{16}$ Other than the difference in interest rates $\left(R^{I}\right.$ versus $\left.R^{B}\right)$, the two payoffs differ in the probability of the creditor making an efficient liquidation decision $(q(c)$ versus $\bar{q})$. It has been assumed that $\bar{q}>q(c)$, which increases the payoff to the property owner in the distressed state when borrowing from a bank. This is the comparative advantage of banks as a source of financing.

An equilibrium consists of a choice of the debt contract by property owners (CMBS debt versus bank debt), the level of resources devoted by investors to evaluating properties in distress, and the interest rates charged by investors and banks. If an owner is in financial distress, the amount of resources investors devote to evaluating the project maximizes their expected payoff. Investors' choice of interest rate is the lowest that gives them nonnegative total expected profits in equilibrium (i.e., competitive bond market). Given the investor choices, owners and banks maximize their expected payoff. The interest rate set by banks in equilibrium is constrained by the fact that each owner has the alternative of financing the property in a CMBS deal with debt investors.

Under these conditions, an equilibrium exists that can be characterized as a separating

\footnotetext{
${ }^{16}$ From a credit risk perspective, this reflects both the probability of default (PD) and the loss given default (LGD).
} 
equilibrium. Safe properties $(S)$ are funded by investors and risky (unsafe) properties $(U)$ are funded by banks. The equilibrium is reflected in the interest rates charged by investors and banks:

$$
\begin{gathered}
R^{I *}=\frac{1-\left(1-p_{S}\right) \pi^{*}}{p_{S}} \\
R^{B *}=R^{I *}+\frac{1-p_{U}}{p_{U}}\left(\delta(1-k) x\left(\bar{q}-q^{*}\right)\right)
\end{gathered}
$$

Banks maximize profits by choosing the highest interest rate consistent with separation of properties and preventing debt investors from making positive expected profits when financing both safe and risky properties. ${ }^{17}$

The equilibrium is a matching process between collateral type and creditor type. The key to our model is the selection between investors and banks by property owners. Safe properties have a higher probability of success, so the owner chooses to borrow at lower rates from CMBS investors. These properties are not likely to require renegotiation. Risky properties have a lower probability of success, so the owner borrows at higher rates from a bank. Owners of risky properties are willing to pay higher interest rates to banks due to the higher likelihood of financial distress and the comparative advantage of banks in evaluating distressed properties.

\section{$3 \quad$ Data and descriptive statistics}

We test our model using data on loans in CMBS deals and commercial real estate loans held in portfolio on bank balance sheets. This combined group of loans on existing, income-producing commercial real estate properties is an ideal setting for studying different sources of secured debt. ${ }^{18}$ The ability to observe CMBS loans and portfolio CRE loans side-by-side, and then compare their

\footnotetext{
${ }^{17} R^{B *}$ is derived from equating equations $(2.4)$ and (2.5). It is the highest interest rate that owners of risky properties are willing to pay for bank debt rather than CMBS debt.

${ }^{18}$ We exclude construction loans for new properties, which are financed almost entirely be financial institutions.
} 
performance over the same time period, provides us with the ability to directly test our hypotheses.

The CMBS data used in this paper are from Morningstar LLC. This loan-level data includes every commercial real estate loan in publicly-issued CMBS deals (including 144A deals) over the period of our sample. Morningstar pulls the information from the Commercial Real Estate Finance Council Investor Reporting Package (CREFC IRP), which standardizes the information provided by loan servicers to the trustees of CMBS pools. ${ }^{19}$ The database is a structured collection, with linked databases for loan, property, tranche, reserves, and much additional data. ${ }^{20}$ It includes loanlevel credit characteristics including the loan balance, loan-to-value (LTV), net operating income (NOI), vacancy rate on the property, and other key components. Morningstar also tracks loan performance, with detailed information on delinquency and, to a lesser extent, loss given default. The data are collected at a monthly frequency starting in the mid-1990s. ${ }^{21}$

The bank data are from the Federal Reserve stress tests. Schedule H.2 of the FR Y-14Q regulatory report is a loan-level data collection of commercial real estate loans on bank balance sheets that supports the annual Comprehensive Capital Analysis and Review (CCAR) stress tests. These data contain the most detailed information on commercial real estate loans the Federal Reserve has ever collected..$^{22}$ The reporting panel has expanded from the original 19 firms in the stress tests to include all bank holding companies with $\$ 50$ billion or more in consolidated assets, 33 firms as of 2014:Q4. Participating firms with material CRE portfolios must complete Schedule H.2 of the FR Y-14 regulatory reporting form for Wholesale Risk, which includes granular data on commercial real estate loans. The loan-level characteristics include measures observed both at origination and throughout the history of the loan. This includes origination date, loan balance,

\footnotetext{
${ }^{19}$ See http://www.crefc.org/irp

${ }^{20}$ Our analysis is based on Morningstar data as of October 2016.

${ }^{21}$ We aggregate the CMBS data to the quarterly frequency to match the frequency of the bank data.

${ }^{22}$ The collection is at the credit facility level, however in most cases the credit facility contains a single loan. We refer to the data as loan-level for simplicity.
} 
property type, loan rate, interest rate type (fixed versus floating), maturity, loan-to-value, and loan purpose (construction, income-producing, owner-occupied). To be included in the data collection the loans must have a minimum size of $\$ 1$ million.

The stress test data provide a quarterly snapshot of the loan portfolio of the initial participating banks beginning in 2012:Q1. The schedule is updated quarterly on a ongoing basis and includes measures of loan status such as extensions, delinquencies, and transition to non-accrual status. The Y-14 bank data are left-censored. When we present data on loans as of a given year of origination, such as the bank loans originated in 2008 and 2009 when the CMBS market was shut down, we are limited only to those bank loans still on the bank balance sheet as of 2012Q1. For the bulk of our analysis, we also restrict our sample of Y-14 loans to banks that were also active originators of loans for securitization.

The combination of these data results in a panel of loans originated by 19 banks with quarterly observations beginning in the first quarter of 2012. For the bulk of our analysis we restrict our sample to CMBS loans originated by banks participating in the Y-14 data collection. Our data exclude loans originated by insurance companies, conduit lenders, and smaller banks. Prior to the development of the CMBS market in the 1990s, insurance companies tended to target large, stabilized, investment-quality properties. Given these lenders' demand for stable long-term cash flows to offset their liabilities, insurance companies naturally preferred to target this segment of properties. The growth of the CMBS market largely came at the expense of the insurance company market and not from banks. ${ }^{23}$ Black, Chu, Cohen, and Nichols (2012) compare loan performance across originator type.

\footnotetext{
${ }^{23}$ Insurance companies are still significant players in the CRE market, originating loans both for their own portfolios and to sell into the CMBS market for securitization. They have shifted some of their CRE exposure away from their whole loan portfolio by investing in higher rate CMBS securities.
} 
Restricting the data to bank originators helps narrow our focus on the choice of the property owner. When a large property needs financing, the property owner typically approaches a large commercial bank with investment bank services. At the bank, there are two underwriting desks: the loan desk and the CMBS desk. Borrowers have a choice between borrowing from the bank and borrowing directly from arm's-length creditors. If the property is financed by a bank loan, the bank commits to monitoring the loan. In contrast, the arm's-length creditors are the CMBS investors. As in corporate finance, property owners can borrow directly from capital markets through CMBS or they can borrow indirectly through a bank.

The summary statistics for our commercial real estate loans at origination are shown in Table 1. Fixed-rate loan is a dummy variable indicating that the loan has a fixed interest rate (versus adjustable), loan amount is the dollar amount of the loan (in millions), debt yield is the ratio of net operating income to the loan balance, loan-to-value is the ratio of the loan amount to the market value of the property, and maturity is the number of years until principal repayment. The table demonstrates that there are clear differences in loan characteristics across the two different funding sources. The most obvious difference is the interest rate type. CMBS investors appear to have an overwhelming preference for fixed-rate loans as opposed to adjustable-rate (99\%). Banks, by contrast, have much less of their portfolio in fixed-rate loans (23\%). While less extreme, there are also differences in key risk factors between bank and CMBS lenders. The average loan-to-value is higher for bank loans and debt yield is lower for bank loans. These differences in risk factors are consistent with prior findings that CMBS loans and bank loans differ significantly in their likelihood of financial distress and renegotiation (Black, Krainer, and Nichols (2017)).

The differences in loan characteristics highlight the endogeneity of loan underwriting to the source of funding. Our model suggests that we should see significant market segmentation based 
on underlying risk in the funding of commercial real estate properties. The descriptive statistics provide initial support for the hypothesis that the commercial real estate market is segmented into two different funding sources.

\section{Identification and the CMBS market shutdown}

In our model, safe collateral is funded by the CMBS market and risky collateral, which is more likely to require renegotiation, is funded by banks. Our identification strategy is designed to test this hypothesis that the market for funding commercial real estate properties is characterized by a sorting equilibrium.

Simply comparing empirical default and renegotiation rates across the two funding sources is problematic because of the potential endogeneity between the funding decision and the characteristics of the loan contract. In the model, banks charge higher rates to compensate for the riskier loans they fund in equilibrium. However, in the data, banks also may impose stricter underwriting terms or loan covenants as part of their risk management. For example, banks may require lower LTVs at origination to help offset the high amount of collateral-specific risk ex ante. Ex post, bank loans could appear (misleadingly) to be safer than CMBS loans in the wake of an aggregate shock to all collateral values like the one experienced during the 2008 financial crisis. Similarly, we cannot definitively tell whether bank loans are more likely to be renegotiated than CMBS loans as a result of contractual features or because banks simply have different preferences for loan renegotiation than CMBS investors or different legal constraints.

Ideally, we would test our hypothesis by conducting an experiment where, controlling for observable characteristics, we would compare default and renegotiation rates on the loans retained in bank portfolios to counterfactual bank default and renegotiation rates on loans in CMBS deals. 
Our solution to this identification problem is to exploit variation over time in the total market share of commercial real estate loans funded in the CMBS market. In our analysis, we treat the collapse of the CMBS market as an exogenous event.

The CMBS market was one of the early casualties of the 2007 financial crisis. CMBS market share had expanded steadily through the early 2000s, but then CMBS spreads started to rise in the spring of 2007. By the summer, banks and other originators of CMBS loans had started to reduce their originations for the CMBS market. However when CMBS spreads dramatically spiked in August, along with spreads on MBS and other structured debt products, many CMBS underwriters still had substantial pipelines of loans in their warehouse facilities. Loan originations for the CMBS market came to a halt. Figure 2 shows how the share of commercial real estate loans funded by CMBS plunged to zero. Even in the first few months of 2008, there was only a trickle of new CMBS issuance as the originators and underwriters tried to reduce their loan pipeline. In several cases underwriters reportedly had to re-purchase the lower rated tranches of the CMBS deal in order to move the loans out of the warehouse.

Following the onset of the crisis, there would not be another CMBS deal until the fall of 2009. Typically a CMBS warehouse facility only holds loans for a few months or less prior to the issuance of a pool backed by the loans. This process is contingent on the ability to anticipate the eventual spread the new CMBS deal would be priced at as well as the anticipated time it would take to structure, rate, and then place the various tranches of the CMBS deal. ${ }^{24}$ However, once the market had shut down, the uncertainty around the spread of a new CMBS deal and the time it would take to bring a deal to market discouraged any firm from being the first to test the market for new issuance. The market did not return to normalcy until after the first (and only) new CMBS

\footnotetext{
${ }^{24}$ In normal times, banks that finance these warehouses can hedge their risk using total return swaps.
} 
issuance financed by the Term Asset-Backed Securities Loan Facility (TALF) in November 2009. The structure and the impact of the TALF program is discussed in detail in Campbell, Covitz, Nelson, and Pence (2011).

The severe liquidity shortages in 2007-2008 affected all asset-backed securities markets (e.g., Gorton and Metrick (2012)), but the conditions leading to the crisis did not originate in commercial real estate. This exogenous event serves as a natural experiment where we can observe the performance of loans that would normally be funded by CMBS, but were not, due to the problems in that funding channel. Our sample of loans backed by income-producing commercial properties is very well-suited for this exercise. The properties in our sample are long-lived assets supported by short-maturity loans; therefore, borrowers with loans maturing during the financial crisis had few options. Owners could refinance their maturing loans into new loans from a bank (or some other institution) or they could default. Figure 2 suggests that, for new originations during the crisis and shortly thereafter, banks were the overwhelming choice of ultimate funding.

During the CMBS market shutdown many property owners turned to banks as an alternative source of funding. Banks were able to expand their portfolio of loans on income-producing properties while reducing their exposure to other market segments, such as construction loans. The ability to finance properties, even during the crisis, is evidence that the main issue was the CMBS funding channel, not the underlying collateral. Despite the sharp drops in property prices over this period, funding from non-CMBS sources remained available. We use the pool of bank loans originated during the CMBS market shutdown to explore the behavior of CMBS-like loans in bank portfolios.

In other words, our paper focuses on identifying the matching of collateral and creditor type. In the pre-crisis period, commercial properties were financed by the CMBS market and by banks. However, when the CMBS market unexpectedly collapsed, banks began financing properties that 
would have been funded in the CMBS market. Therefore, the CMBS shutdown effectively shut down the matching process and, in the post-crisis period, banks financed both types of collateral. This allows us to control for creditor type and compare the performance of the underlying collateral.

\section{$5 \quad$ Empirical methodology and results}

Our empirical analysis focuses on commercial real estate loans funded by banks in the period following the CMBS market shutdown. We want to compare loans traditionally funded by banks with loans that would have been funded in the CMBS market. The natural experiment of the CMBS market shutdown provides an opportunity to observe different types of collateral being funded by a single type of creditor. The key test is a comparison of the likelihood of default or renegotiation for these different types of loans on bank balance sheets in the post-CMBS collapse period. We use several different proxies for CMBS funding to indicate loans that would have been funded in the CMBS market. The prediction from our model is that these loans should be less likely default or require renegotiation. In other words, collateral that is funded by arm's-length investors in normal times tends to be safe collateral.

Our methodology follows a two-step approach designed around the exogenous shock to CMBS funding. The first step is to determine an indicator for predicting CMBS funding. One indicator is simply to observe whether the loan has a fixed interest rate. Loans financed in the CMBS market prior to the shutdown were almost entirely fixed rate. Another indicator is the estimated probability of CMBS financing based on loans originated in the pre-2007 period. ${ }^{25}$ These estimates include other contractual features including whether the loan is fixed rate. In the second step of our analysis, we use the fixed-rate indicator and the fitted probabilities from the regression

\footnotetext{
${ }^{25}$ The regression models are similar in specification to Black, Krainer, and Nichols (2014).
} 
model and apply these to the post-2007 loan originations funded by banks. Our goal is to compare two different types of bank loans following the CMBS shutdown: the loans traditionally funded by banks and the loans that would have been funded by the CMBS market. With this approach, we can compare the performance of the two types of loans apart from the differences in creditor type. Our benchmark specification for estimating the probability of CMBS financing is as follows:

$$
\operatorname{Prob}(C M B S)=f(\text { fixed-rate loan, loan amount, debt yield, loan-to-value, maturity }) .
$$

This basic regression estimates the likelihood of a loan being financed in the CMBS market based on the characteristics of the loan. The five independent variables in the benchmark specification are all loan characteristics at the time of loan origination. Fixed-rate loan differentiates loans based on whether the loan payments are fixed or floating rate, loan amount (in logs for scaling) closely relates to the size of the property being financed, debt yield is a measure of the property's profitability, loan-to-value is the leverage of the property, and maturity is the term of the loan in years.

We expand this basic specification with fixed effects and additional controls. Commercial real estate properties differ qualitatively based on property type. The property types in our sample include office, industrial, hotel, multifamily, and retail. To account for this, we include property type fixed effects. The likelihood of CMBS financing may depend on the particular originating bank as well, so we include bank fixed effects to account for bank heterogeneity. ${ }^{26}$ These bank fixed effects function as "originator" fixed effects for banks that originate loans for the CMBS market and their own balance sheet. Lastly, loans may differ based on market characteristics. We take two approaches to control for local market conditions in the metropolitan statistical area (MSA). $\sqrt[26]{\text { Titman and Tsyplakov }}(2010)$ find evidence that loan screening standards for commercial mortgages can differ
across originators based on the bank's performance. 
We include the current unemployment rate for the local county and the local year-over-year house price appreciation as controls. In addition, our final specification includes MSA fixed effects.

The results for the estimated probability of CMBS financing for pre-crisis loan originations (prior to 2007) are shown in Table 2. One of the strongest results is the positive and significant coefficient on the fixed-rate dummy, indicating that loans with a fixed interest rate are much more likely to be funded in the CMBS market. This is likely because loans funded in the CMBS market are the collateral for fixed-income securities issued to bond investors. A number of the other coefficient estimates also demonstrate how loan characteristics depend on whether the eventual holder of the loan is a CMBS investor or a bank. For instance, we see that the coefficient on loan-to-value at origination is positive, which could reflect banks attempting to mitigate borrower risk by requiring lower LTVs at origination (Titman, Tompaidis, and Tsyplakov 2005). The results in Table 2 point to the potential endogeneity problem when relating funding source and other outcomes to loan characteristics. This highlights the need for an identification strategy that can isolate a single funding source during the crisis.

With pre-crisis model estimates in hand, we generate fitted probabilities of CMBS financing for loans originated during and after the financial crisis (2007 and later). Many of the bank loans originated during this period have a very high probability of CMBS funding, which indicates that these loans would have been financed in the CMBS market if it had not shut down. Figure 4 illustrates this point by showing the distribution of fitted probabilities for fixed-rate loans originated in 2007, 2008, and 2009. We limit the sample to fixed-rate loans for this figure to show that more than half of the loans funded by banks were not traditional bank loans. In all three years, the probability density is highest between 80 percent and 100 percent probability of securitization. We also observe a drift in the distribution of fitted probabilities for CMBS funding over time. By 2009, 
average probabilities of CMBS funding for this subsample of loans are falling. We interpret this result as being due to adjustments in other loan terms that the banks were gradually enforcing in the aftermath of the collapse of the CMBS market. Fixed-rate loans are always more likely to be securitized than adjustable-rate loans, but the power of the fixed-rate indicator alone steadily became a less reliable indicator of securitization as the weakness in that market persisted. This time-variation in loan characteristics is evidence for the way that banks shape loan contracts and offer a different type of intermediation than CMBS investors.

To test our hypothesis about market segmentation in commercial real estate funding, we estimate logit models of default and renegotiation for bank loans in the post-CMBS collapse period. This analysis is based on loans originated post-2007 and retained in bank portfolios, including both fixed-rate and adjustable-rate loans. We measure renegotiation by loan extension (an increase in loan maturity), which is the most common form of renegotiation in the banking data. Our main specification for estimating the probability of default or extension is as follows:

$\operatorname{Prob}($ Default or extension $)=f(C M B S$ indicator, loan characteristics, fixed effects $)$.

The key explanatory variable is the CMBS indicator, for which we include three different proxies for CMBS funding. The first is a dummy variable indicating loans with a fixed interest rate. This is our first and most basic indicator for the likelihood of securitization, which follows earlier work on the fixed-rate mortgage (Fuster and Vickery 2014). The second is the fitted probability of CMBS funding based on the model in column (i) of Table 2. Lastly, we include a dummy variable indicating a fitted CMBS funding probability in the 75th percentile of the distribution. Various specifications include vintage, property type, and bank fixed effects. 
The results are found in Tables 3 and 4 . In Table 3 we base our definitions of default and extension on whether the loan was in default or extension as of 2012Q1. In Table 4, we consider loans that were reported as current in 2012Q1 but then subsequently transitioned to default or were extended. This distinction is based on the availability of the bank stress test data beginning in 2012Q1. All specifications include vintage effects to control for time-specific heterogeneity in loan performance associated with a particular origination year. Specifications iii and vi of Table 4 include a full set of vintage, property, and bank fixed effects. All estimates include robust standard errors.

The results in Table 3 show the relationship of the CMBS proxies to default and extension. Focusing first on the default models in the upper panel of Table 3, the securitization proxies generally have the expected negative sign, implying that loans were less likely to default that were relatively more likely to have been securitized. However, the standard errors in these regressions are large and the estimated effects are not significant. Thus, the evidence for our story of sorting in the CRE loan market is only weakly corroborated in the default regressions. By contrast, the loan extension models in Table 3 all show a strong and significant negative relation between loan extension and the securitization proxies. This differential implies that higher renegotiation probabilities of the loans considered likely to be portfolio loans may also be masking risk differences. If banks are preempting default through the renegotiation channel, we would probably see higher default rates in the traditional bank loan portfolio. Loan extensions prior to maturity are not randomly occurring events, but are forms of remediation that banks use to limit losses and avoid inefficient default costs.

The results in Table 4 show a stronger negative relationship between our indicators of CMBS funding and default. In particular, loans with a fixed interest rate are significantly less likely to 
default than loans with an adjustable interest rate (columns vii-ix). As discussed earlier, a fixed interest rate is key indicator of loan that was likely to be funded in the CBMS market. The lower probability of default for these fixed-rate loans points to strong cash flows in the underlying commercial property. This implies that the CMBS market typically funds safe collateral, not risky collateral.

To summarize, the basic results are consistent with the theory of safe collateral being funded by the arm's-length investors in the CMBS market and riskier, information-sensitive collateral being funded by banks. When the CMBS market shut down and safe collateral could no longer be funded with CMBS, we see generally lower default rates and significantly lower renegotiation rates for loans with CMBS-like attributes.

\section{Performance of matched CMBS refinanced loans}

In this section, we explore an alternative strategy for determining CMBS-like loans in bank portfolios during the CMBS shutdown. Rather than using the imputed probability of CMBS funding, we attempt to identify specific properties secured by CMBS loans that resolved during the CMBS market shutdown and match them with specific bank loans that were originated at approximately the same time and observable in the bank data. A matched pair suggests that a bank directly refinanced the maturing CMBS loan after the shutdown of the CMBS market.

The initial set of CMBS loans used in this analysis consists of all CMBS loans that resolved (i.e., were paid-off or liquidated) in 2007, 2008, or 2009. The properties securing these loans are then paired through a matching algorithm based on property type, zip code, and when available, property value and property size. ${ }^{27}$ To account for CMBS loans secured by multiple properties,

\footnotetext{
${ }^{27}$ Over 100 of the matches are based on the property value in the bank data being within 25 percent of the value in
} 
these fields are based on the property level schedule provided by Morningstar. The CMBS loans are compared with bank loans that were originated within 90 days of the resolution of the CMBS loan. ${ }^{28}$ When there is more than one bank loan originated in this period with the same property type and in the same zip code as the CMBS property, we match based on the closest reported property size, property value, or date of origination, depending on data availability. This process generated 373 properties with resolved CMBS loans matched to new bank financing. ${ }^{29}$ The relatively small number of resolved CMBS loans that we can match to bank originations suggests that CMBS borrowers may have used non-bank financing, such as insurance companies and REITs, to finance other properties.

Table 5 compares the characteristics of the CMBS-to-bank refinancings to other traditional bank originations. The CMBS-to-bank refinancings are dominated by multifamily loans. Multifamily loans constitute a significant, but much smaller, share of all other bank originations over this period. The differences in the risk measures between the two types of loan produce mixed signals. On the one hand the refinancings have slightly lower LTVs and higher occupancy rates. Yet they also have lower debt yields and higher interest rates. The endogeneity between pricing and underwriting makes interpretation of these signals difficult. A low LTV could signal a riskier borrower for which the lender has demanded a larger equity position, or it could simply reflect a less leveraged and hence less risky property. Looking at both realized performance between 2012:Q1 and 2015:Q3 we see that the CMBS-to-bank refinancings had significantly lower rates of default and extension. This is consistent with the hypothesis that the CMBS market had previously attracted more stable

the CMBS data. About 40 matches include matching based on property size.

${ }^{28}$ The bank data in the Y-14 is reported at the credit facility level, not the property level. This prevents us from successfully matching new bank loans where multiple CMBS properties are refinanced within the same credit facility. Results produced when matching the CMBS loan level data instead of the property level data produces a similar magnitude of matching, with similar results.

${ }^{29}$ The results are similar when we replicate the analysis excluding matches where we only have information on property type and location. 
properties with lower idiosyncratic risk, and the higher rate of default in the CMBS market during the crisis reflected the higher leverage and less flexible loss mitigation strategies available to special servicers.

We re-estimate the models from the previous section using a CMBS refinance indicator variable for properties that were likely refinanced from CMBS debt to bank debt. The results for the models of the loan status as of 2012Q1 are reported in Table 6. In Panel A, the loan characteristics (loan amount, LTV, and occupancy) are all as of 2012Q1. The coefficients for the risk drivers (current LTV and current occupancy) are similar, with loans with higher leverage and lower occupancy being more likely to experience distress and either default or be extended. The impact of loan amount switches sign, negative and significant in the default models and positive and significant for the extension models. This pattern may reflect banks' greater incentive to modify larger loan exposures. While not shown, the property type fixed effects show that loans on retail properties are significantly more likely to have been extended by $2012 \mathrm{Q} 1$ and multifamily loans are both less likely to have been default or been extended by 2012Q1. The signs of the CMBS refinance indicator in the default models are insignificant as in the baseline model. The CMBS refinance indicator is negative for the extension models and the coefficients are just outside the $10 \%$ significance range. While these results are weaker than those in the previous section, they are not inconsistent with our hypothesis that under normal market conditions CMBS loans are secured by more stable properties.

Our final specifications modeling loan performance from 2012:Q1 to 2015:Q3 for those loans current as of 2012:Q1 are shown in Panel B of Table 6. The loan amount, LTV, and occupancy are all as of 2012:Q1. The results show that loans that were more highly leveraged at the beginning of this period were more likely to experience distress and either default or require extension by 
2015:Q3. The occupancy as of 2012:Q1 is significant and negative only for the default measure and the loan balance is significant and negative only for the extension measure. This result is similar to the prior result, suggesting that banks may have a greater incentive to modify larger loans, controlling for collateral performance. While not shown, the property type fixed effects show that all property types are less likely to default than loans on offices, the reference category. In particular hotel and multi-family loans are significantly less likely to default than retail and industrial loans.

The results for the CMBS refinance indicator in Table 6, Panel B, are similar to the baseline results. The coefficient is negative for all specifications and significant for the first two sets of specifications. Once the bank and property effects are introduced, the CMBS refinance indicator remains negative, but is no longer significant. These results support our hypothesis that the CMBS loans, even once they migrate to the bank portfolio, still have lower levels of credit risk and require fewer loan extensions.

\section{Conclusion}

Our paper is about the matching of collateral and creditor types. When assets are financed with debt, the source of the debt is very important during periods of financial distress. This creates a matching process at origination. Which types of creditors finance safe assets and which finance risky assets? Our question cuts across a number of traditional contracting issues in corporate finance. However, we focus on the unique market of commercial real estate. As a fixed asset, commercial real estate provides an ideal setting for exploring the issue of secured debt.

We develop a theoretical model that explains the separation in commercial real estate debt between the securitized commercial mortgage-backed securities (CMBS) market and bank loans. The model predicts that the private information of property owners and differences in monitoring 
costs for evaluating financial distress are sufficient to generate a separating equilibrium with riskier loans going to bank portfolios.

Previous empirical analysis on the separation of the CMBS and bank loan portfolios was limited by the endogeneity of the loan origination process. A loan originated for CMBS will have fundamentally different underwriting terms than a loan originated for a bank portfolio and these terms may not be observable to the researcher. This paper uses the period of the shutdown in the CMBS market during the financial crisis to overcome the endogeneity challenge. During the shutdown of the CMBS market, banks entered the property segment historically served by CMBS investors. Our empirical results indicate that these bank loans - originated during the CMBS shutdown and strongly resembling CMBS loans - were less likely to default or require extensions, consistent with our theoretical model. In other words, properties historically funded by arm'slength creditors appear to be safer collateral. We develop a second empirical approach that matches specific CMBS loans that resolved during the shutdown with newly originated bank loans. This approach provides some support for our theory as well.

The results of our paper offer a new perspective on the role of the securitization market. For commercial real estate, the CMBS market appears to be a low-cost, arm's-length source of funding for relatively safe collateral. This type of funding can be very attractive for financing properties that are not likely to experience financial distress. However, in the event of distress, CMBS financing can result in inefficient liquidation. Bank debt provides a higher-cost, more informed source of secured debt. The financial intermediation of commercial banking is ideally suited to funding risky collateral that may require renegotiation. 


\section{References}

Agarwal, S., G. Amromin, I. Ben-David, S. Chomsisengphet, and D. Evanoff (2011): "The role of securitization in mortgage renegotiation," Journal of Financial Economics, 102, $559-578$.

Arrow, K. J. (1974): "Limited information and economic analysis," American Economic Review, $64,1-10$.

Benmelech, E., M. Garmaise, and T. Moskowitz (2005): "Do liquidation values affect financial contracts? Evidence from commercial loan contracts and zoning regulation," The Quarterly Journal of Economics, 120, 1121-1154.

Berger, A., And G. Udell (2006): "A more complete conceptual framework for SME finance," Journal of Banking and Finance, 30, 2945-2966.

Black, L., C. Chu, A. Cohen, and J. Nichols (2012): "Differences across originators in CMBS loan underwriting," Journal of Financial Services Research, 42, 115-134.

Black, L., J. Krainer, and J. Nichols (2017): "From origination to renegotiation: A comparison of portfolio and securitized commercial real estate loans," The Journal of Real Estate Finance and Economics, 55, 1-31.

Bolton, P., and D. S. Scharfstein (1996): "Optimal debt structure and the number of creditors," Journal of Political Economy, 104, 1-25.

Boot, A. W., And A. V. Thakor (1994): "Moral hazard and secured lending in an infinitely repeated credit market game," International Economic Review, 35, 899-920.

Calomiris, C., M. Larrain, J. Liberti, and J. Sturgess (2017): "How collateral laws shape lending and sectoral activity," Journal of Financial Economics, 123, 163-188.

Campbell, S., D. Covitz, W. Nelson, and K. Pence (2011): "Securitization markets and central banking: An evaluation of the term asset-backed securities loan facility," Journal of Monetary Economics, 58, 518-531.

Cerqueiro, G., S. Ongena, and K. Roszbach (2016): "Collateralization, bank loan rates, and monitoring," Journal of Finance, 71, 1295-1322.

Diamond, D. (1991): "Monitoring and reputation: the choice between bank loans and directly placed debt," Journal of Political Economy, 99, 689-721. 
Downs, D. H., And P. T. XU (2015): "Commercial real estate, distress and financial resolution: Portfolio lending versus securitization," The Journal of Real Estate Finance and Economics, 51, $254-287$.

Fuster, A., And J. Vickery (2014): "Securitization and the fixed-rate mortgage," Review of Financial Studies, 28, 176-211.

GAN, J. (2007): "Collateral, debt capacity, and corporate investment: Evidence from a natural experiment," Journal of Financial Economics, 85, 709-734.

Ghent, A., and R. Valkanov (2016): "Comparing securitized and balance sheet loans: Size matters," Management Science, 62, 2784-2803.

HART, O., And J. Moore (1998): "Default and renegotiation: A dynamic model of debt," The Quarterly Journal of Economics, 113, 1-41.

JAMES, C. (1987): "Some evidence on the uniqueness of bank loans," Journal of Financial Economics, 19, 217-235.

Piskorski, T., A. Seru, and V. Vig (2010): "Securitization and distressed loan renegotiations: Evidence from the subprime mortgage crisis," Journal of Financial Economics, 97, 369-397.

RAJAn, R. (1992): "Insiders and outsiders: The choice between informed and arm's-length debt," Journal of Finance, 47, 1367-1400.

Rajan, R., And A. Winton (1995): "Covenants and collateral as incentives to monitor," Journal of Finance, 50, 1113-1146.

Titman, S., S. Tompaidis, and S. Tsyplakov (2005): "Determinants of credit spreads in commercial mortgages," Real Estate Economics, 33, 711-738.

Titman, S., And S. Tsyplakov (2010): "Originator performance, CMBS structures, and the risk of commercial mortgages," Review of Financial Studies, 23, 3558-3594.

VIG, V. (2013): "Access to collateral and corporate debt structure: Evidence from a natural experiment," Journal of Finance, 68, 881-928. 
Figure 1:

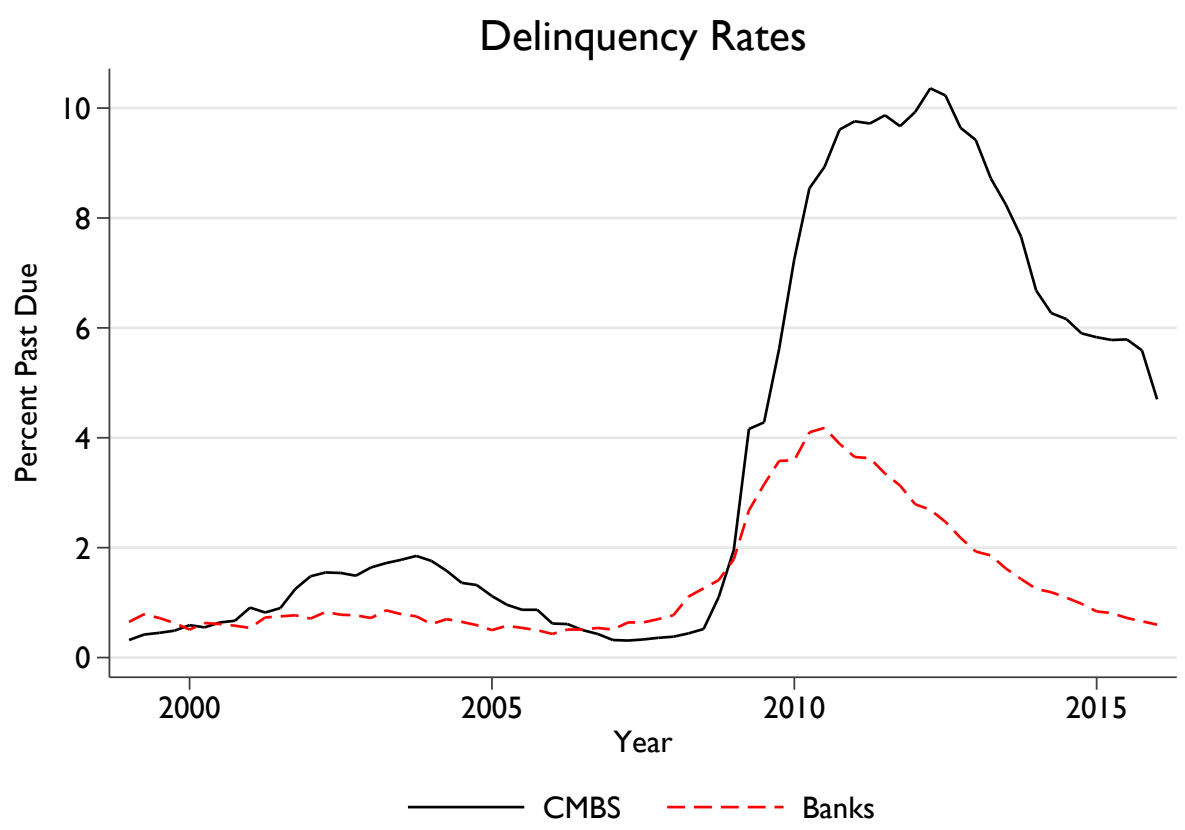

This figure shows the delinquency rates for commercial real estate loans in CMBS pools and in bank portfolios, respectively. Delinquency rate is based on the share of outstanding loans that are 30 days or more past due for both series. Sources: Citi Research - Securitized Products (CMBS) and Call Reports (Banks). 
Figure 2:

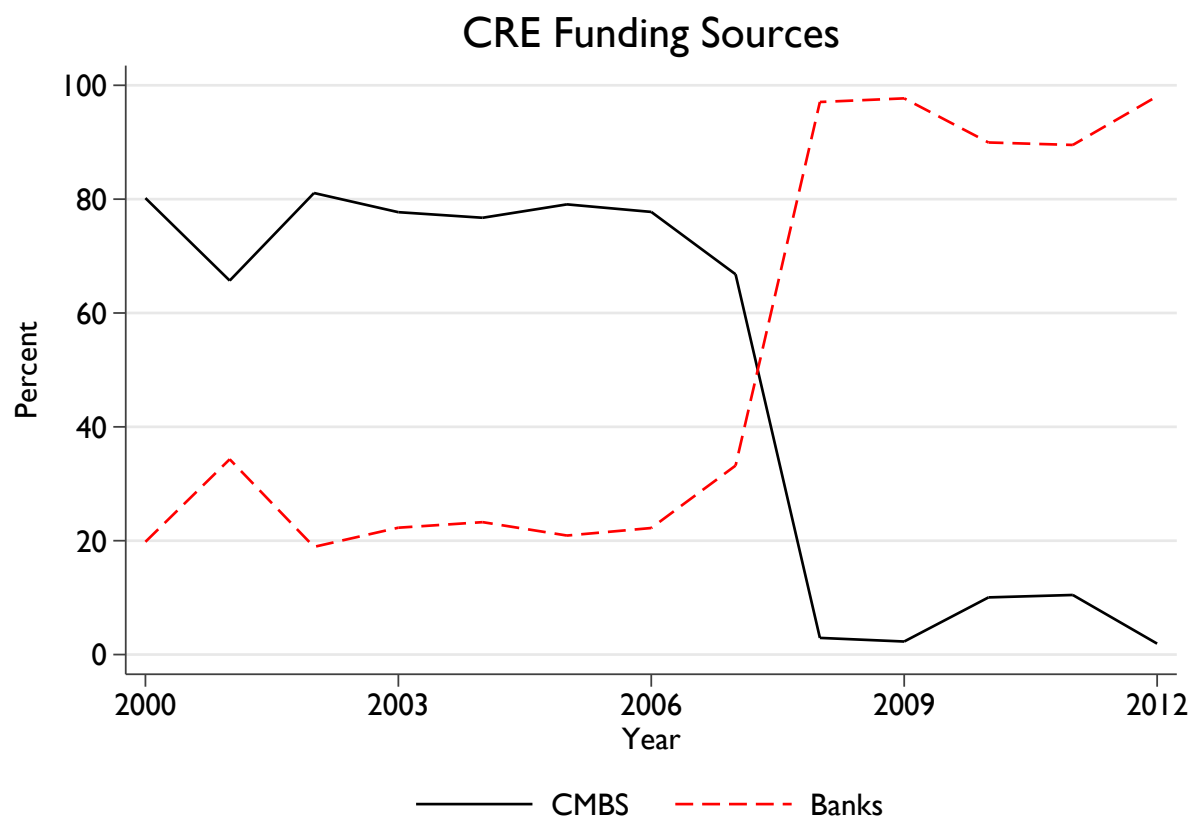

This figure shows the percent of commercial real estate loans funded by the CMBS market and banks, respectively. The collapse of the CMBS market occurred in the fall of 2007. Sources: Morningstar (CMBS) and FR Y-14Q Schedule H.2 (Banks). 
Figure 3:

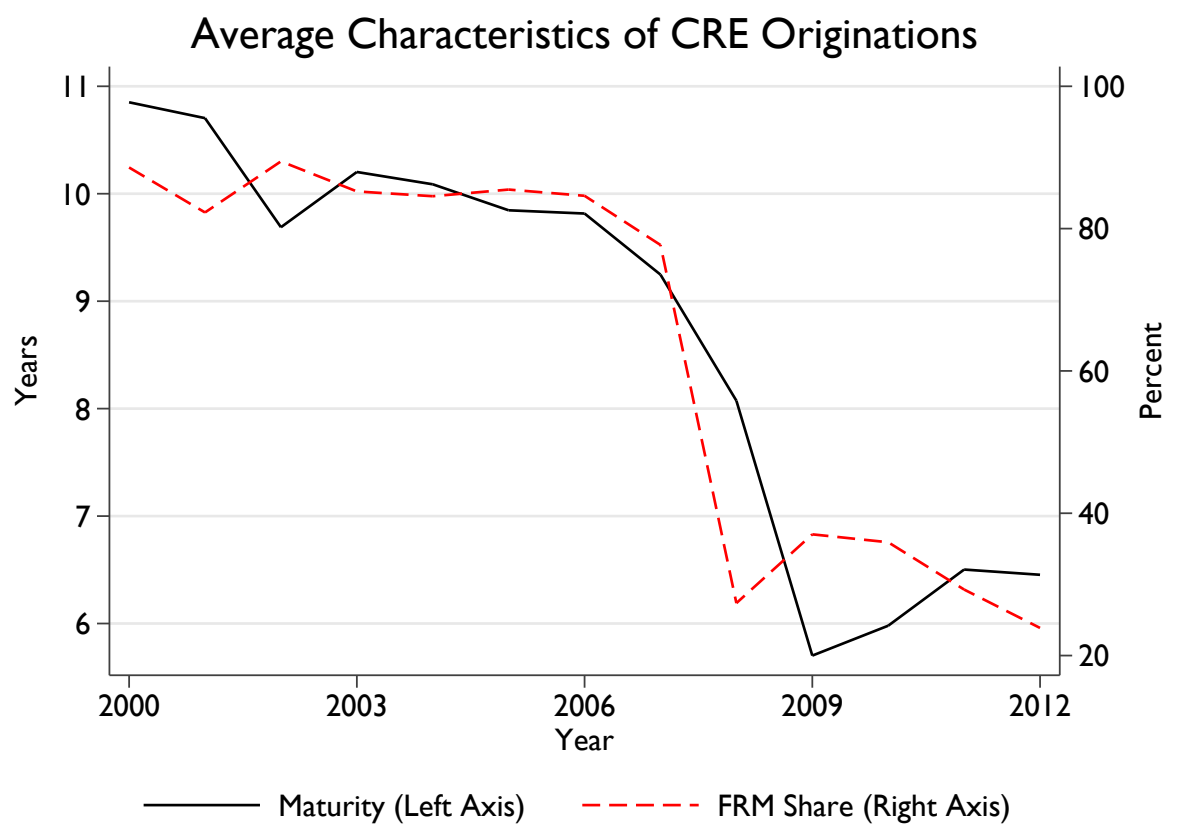

This figure shows the average maturity (left axis) and average share of fixed-rate mortgages (right axis) for commercial real estate originations. Averages are calculated across the combined data of CMBS loans and bank loans. Sources: Morningstar (CMBS) and FR Y-14Q Schedule H.2 (Banks). 
Figure 4:

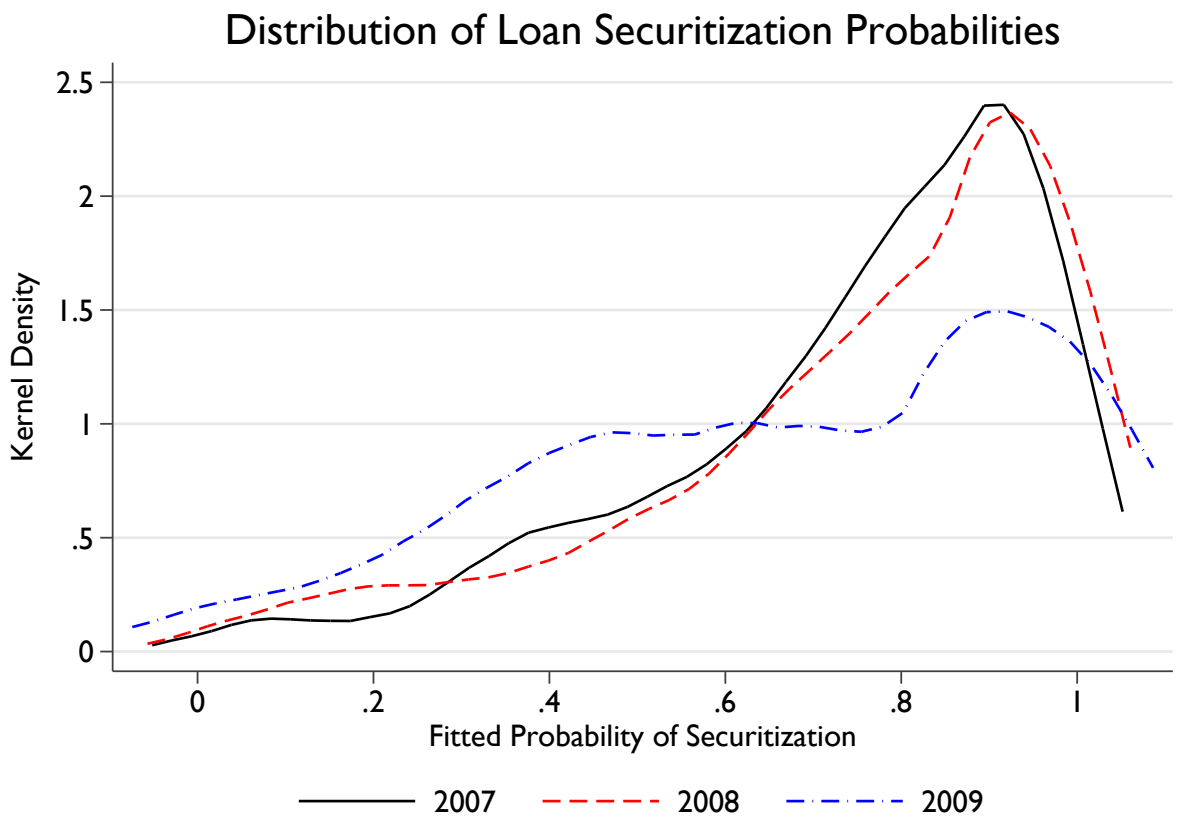

This figure shows the distribution of fitted loan securitization probabilities for 2007, 2008, and 2009. Density estimates are based on fixed-rate loans originated for bank portfolios in each year. Estimated model coefficients are from pre2007 data including both fixed-rate and adjustable-rate loans. Sources: Analysis based on data from Morningstar (CMBS) and FR Y-14Q Schedule H.2 (Banks). 


\section{Table 1: Characteristics of commercial real estate loans at origination}

This table reports the characteristics of commercial real estate (CRE) loans at origination for the CMBS market and for banks. Amounts shown are averages of the sample of CRE loans in CMBS and in bank portfolios. The full sample includes the pre-crisis and post-crisis periods. Statistics are also shown for these two subsamples. CMBS data are from Morningstar and bank data are from FR Y-14Q Schedule H.2.

\begin{tabular}{|c|c|c|c|c|c|c|}
\hline & (i) & (ii) & (iii) & (iv) & $(\mathrm{v})$ & (vi) \\
\hline & $\begin{array}{l}\text { Number } \\
\text { of loans }\end{array}$ & $\begin{array}{l}\text { Fixed-rate } \\
\text { loan }(0 / 1)\end{array}$ & $\begin{array}{l}\text { Loan amount } \\
\text { (millions) }\end{array}$ & Debt yield & $\begin{array}{l}\text { Loan-to- } \\
\text { value }\end{array}$ & $\begin{array}{c}\text { Maturity } \\
\text { (years) }\end{array}$ \\
\hline \multicolumn{7}{|c|}{ Full Sample Period } \\
\hline CMBS & 20,281 & $99.4 \%$ & 16 & $11.6 \%$ & $69.1 \%$ & 9.8 \\
\hline Bank & 25,817 & $23.4 \%$ & 5.5 & $12.9 \%$ & $60.0 \%$ & 8.3 \\
\hline \multicolumn{7}{|c|}{ Pre-Crisis (2007 and earlier) } \\
\hline CMBS & 19,448 & $99.0 \%$ & 15.5 & $11.5 \%$ & $69.3 \%$ & 9.9 \\
\hline Bank & 10,575 & $29.7 \%$ & 3.6 & $12.1 \%$ & $61.9 \%$ & 10 \\
\hline \multicolumn{7}{|c|}{ Crisis and Post-Crisis (2008 and later) } \\
\hline CMBS & 833 & $98.9 \%$ & 38 & $12.7 \%$ & $63.9 \%$ & 8.6 \\
\hline Bank & 15,242 & $19.0 \%$ & 6.9 & $13.5 \%$ & $58.2 \%$ & 7.1 \\
\hline
\end{tabular}




\section{Table 2: Likelihood of CMBS financing prior to the crisis}

This table shows results of prediction model for estimating the likelihood of CMBS financing for commercial real estate loans. The dependent variable is a dummy variable that takes the value of 1 for loans in a CMBS pool. All independent variables are values at origination. Estimation sample is based on all loans originated prior to 2007. The sample consists of all CRE loans originated by large banks active in origination for CMBS market. The model is estimated with a logit specification. Robust standard errors in parentheses. ${ }^{* * *} \mathrm{p}<0.01,{ }^{* *} \mathrm{p}<0.05,{ }^{*} \mathrm{p}<.1$.

\begin{tabular}{|c|c|c|c|c|}
\hline & (i) & (ii) & (iii) & (iv) \\
\hline Fixed-rate loan & $\begin{array}{c}6.616^{* * *} \\
(0.136)\end{array}$ & $\begin{array}{c}7.830^{* * *} \\
(0.268)\end{array}$ & $\begin{array}{c}10.326^{* * *} \\
(1.407)\end{array}$ & $\begin{array}{c}11.992^{* * *} \\
(2.141)\end{array}$ \\
\hline Loan amount (log) & $\begin{array}{c}0.487^{* * *} \\
(0.028)\end{array}$ & $\begin{array}{c}1.062^{* * *} \\
(0.047)\end{array}$ & $\begin{array}{c}1.232^{* * *} \\
(0.314)\end{array}$ & $\begin{array}{c}1.364^{* * *} \\
(0.391)\end{array}$ \\
\hline Debt yield & $\begin{array}{c}1.764^{* * *} \\
(0.533)\end{array}$ & $\begin{array}{c}4.545^{* * *} \\
(1.039)\end{array}$ & $\begin{array}{c}31.970 \\
(19.607)\end{array}$ & $\begin{array}{c}57.925^{* * *} \\
(14.919)\end{array}$ \\
\hline Loan-to-value & $\begin{array}{c}2.858^{* * * *} \\
(0.224)\end{array}$ & $\begin{array}{c}3.485^{* * *} \\
(0.371)\end{array}$ & $\begin{array}{c}10.097^{* *} \\
(4.070)\end{array}$ & $\begin{array}{c}13.505^{* * *} \\
(3.760)\end{array}$ \\
\hline Maturity & $\begin{array}{c}0.014 \\
(0.037)\end{array}$ & $\begin{array}{c}-0.137^{*} \\
(0.072)\end{array}$ & $\begin{array}{c}0.116 \\
(0.345)\end{array}$ & $\begin{array}{l}-0.286 \\
(0.226)\end{array}$ \\
\hline Unemployment rate & & & $\begin{array}{c}1.164^{* * *} \\
(0.134)\end{array}$ & $\begin{array}{c}1.319^{* * *} \\
(0.275)\end{array}$ \\
\hline House price appreciation & & & $\begin{array}{c}-43.941^{* * *} \\
(5.740)\end{array}$ & $\begin{array}{c}-55.231^{* * *} \\
(13.877)\end{array}$ \\
\hline Constant & $\begin{array}{c}-13.755^{* * *} \\
(0.625)\end{array}$ & $\begin{array}{c}-21.672^{* * *} \\
(1.224)\end{array}$ & $\begin{array}{c}4.693 \\
(10.999)\end{array}$ & $\begin{array}{c}20.070 \\
(14.357)\end{array}$ \\
\hline Property type fixed effects & no & yes & yes & yes \\
\hline Bank fixed effects & no & yes & yes & yes \\
\hline MSA fixed effects & no & no & no & yes \\
\hline Observations & 37,146 & 17,590 & 12,447 & 9,020 \\
\hline Pseudo R-squared & 0.499 & 0.688 & 0.847 & 0.899 \\
\hline
\end{tabular}


Table 3: Likelihood of default or extension for commercial real estate loans as of 2012Q1

This table shows the estimated coefficients in the prediction model for estimating the likelihood of default or extension for commercial real estate loans after the crisis. The dependent variables of default (Panel A) and extension (Panel B) are based on whether the loan was in default or extended as of 2012Q1. In Panel A, the dependent variable is a dummy variable indicating loans that were in default (nonperforming). In Panel B, the dependent variable is a dummy variable indicating loans that were extended. Fitted securitization probabilities are computed from model (i) in Table 2. High securitization probability is a dummy variable indicating that the probability of securitization is in the 75th percentile. Loan characteristics (amount, loan-to-value, occupancy) are in current values. Estimation sample is based on all loans originated after 2006. The sample consists of all CRE loans originated by large banks active in origination for CMBS market. The model is estimated with a logit specification. Robust standard errors in parentheses. $* * *$ p $<0.01, * *$ $\mathrm{p}<0.05,{ }^{*} \mathrm{p}<.1$

Panel A:

Loan Default

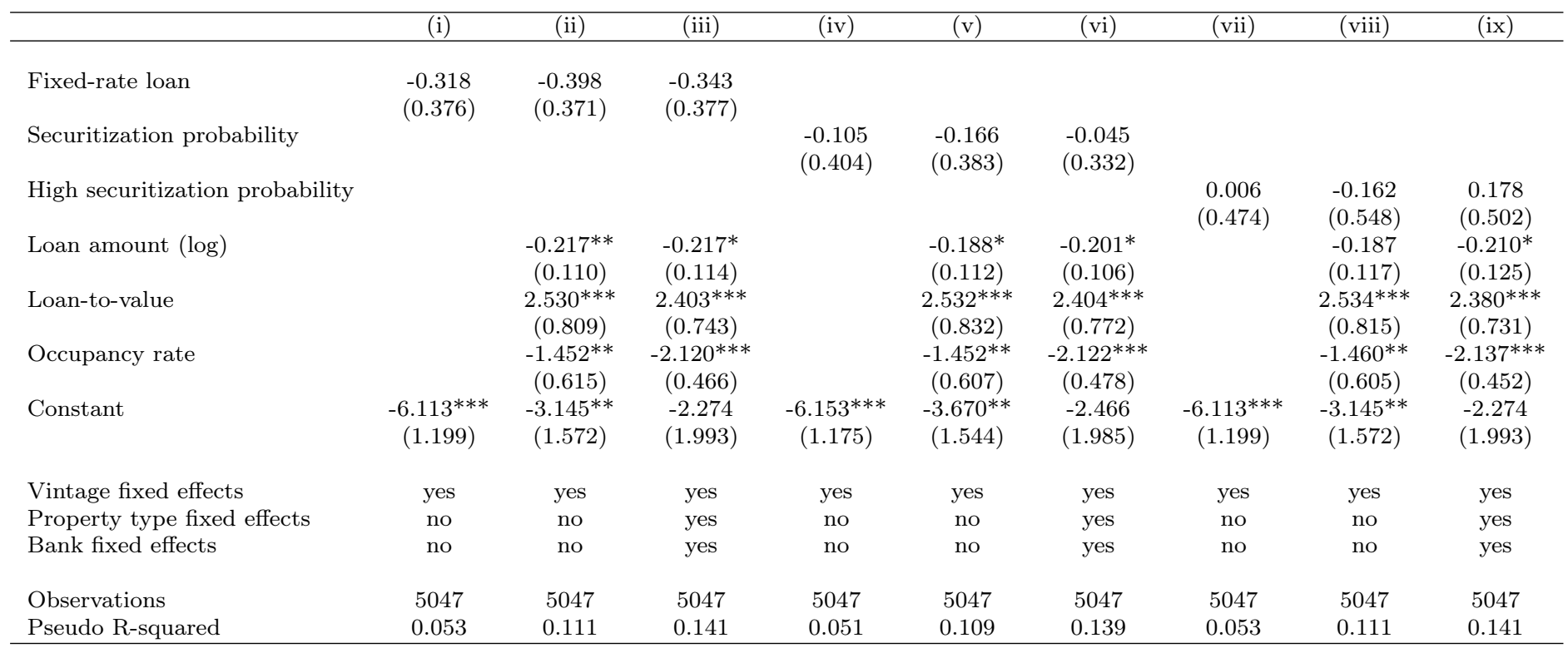


Table 3 cont.: Likelihood of default or extension for commercial real estate loans as of 2012Q1

Panel B:

\begin{tabular}{|c|c|c|c|c|c|c|c|c|c|}
\hline & \multicolumn{9}{|c|}{ Loan Extension } \\
\hline & (i) & (ii) & (iii) & (iv) & (v) & (vi) & (vii) & (viii) & (ix) \\
\hline Fixed-rate loan & $\begin{array}{c}-1.069^{* * *} \\
(0.418)\end{array}$ & $\begin{array}{c}-1.121^{* * * *} \\
(0.431)\end{array}$ & $\begin{array}{c}-1.296 * * * \\
(0.366)\end{array}$ & & & & & & \\
\hline Securitization probability & & & & $\begin{array}{c}-0.968^{*} \\
(0.495)\end{array}$ & $\begin{array}{c}-1.045^{* *} \\
(0.459)\end{array}$ & $\begin{array}{c}-1.012^{* *} \\
(0.413)\end{array}$ & & & \\
\hline High securitization probability & & & & & & & $\begin{array}{c}-1.194^{* *} \\
(0.487)\end{array}$ & $\begin{array}{c}-1.265 * * * \\
(0.475)\end{array}$ & $\begin{array}{c}-1.145^{* *} \\
(0.446)\end{array}$ \\
\hline Loan amount (log) & & $\begin{array}{l}-0.082 \\
(0.097)\end{array}$ & $\begin{array}{l}-0.060 \\
(0.109)\end{array}$ & & $\begin{array}{c}0.008 \\
(0.089)\end{array}$ & $\begin{array}{c}0.021 \\
(0.106)\end{array}$ & & $\begin{array}{l}-0.005 \\
(0.069)\end{array}$ & $\begin{array}{c}0.015 \\
(0.090)\end{array}$ \\
\hline Loan-to-value & & $\begin{array}{c}1.382^{* * * *} \\
(0.463)\end{array}$ & $\begin{array}{c}1.336^{* * *} \\
(0.493)\end{array}$ & & $\begin{array}{c}1.440^{* * *} \\
(0.501)\end{array}$ & $\begin{array}{c}1.420^{* * *} \\
(0.530)\end{array}$ & & $\begin{array}{c}1.402^{* * *} \\
(0.500)\end{array}$ & $\begin{array}{l}1.372^{* *} \\
(0.537)\end{array}$ \\
\hline Occupancy rate & & $\begin{array}{l}-0.533 \\
(0.454)\end{array}$ & $\begin{array}{l}-0.827^{*} \\
(0.438)\end{array}$ & & $\begin{array}{l}-0.569 \\
(0.417)\end{array}$ & $\begin{array}{l}-0.782^{*} \\
(0.436)\end{array}$ & & $\begin{array}{l}-0.595 \\
(0.396)\end{array}$ & $\begin{array}{l}-0.812^{*} \\
(0.438)\end{array}$ \\
\hline Constant & $\begin{array}{c}-0.397^{* *} \\
(0.201)\end{array}$ & $\begin{array}{c}0.517 \\
(1.094)\end{array}$ & $\begin{array}{c}0.640 \\
(1.094)\end{array}$ & $\begin{array}{l}-0.359 \\
(0.226)\end{array}$ & $\begin{array}{l}-0.842 \\
(0.983)\end{array}$ & $\begin{array}{l}-0.582 \\
(1.053)\end{array}$ & $\begin{array}{c}-0.525 * * * \\
(0.192)\end{array}$ & $\begin{array}{l}-0.777 \\
(0.611)\end{array}$ & $\begin{array}{l}-0.630 \\
(0.770)\end{array}$ \\
\hline Vintage fixed effects & yes & yes & yes & yes & yes & yes & yes & yes & yes \\
\hline Property type fixed effects & no & no & yes & no & no & yes & no & no & yes \\
\hline Bank fixed effects & no & no & yes & no & no & yes & no & no & yes \\
\hline Observations & 5047 & 5047 & 5047 & 5047 & 5047 & 5047 & 5047 & 5047 & 5047 \\
\hline Pseudo R-squared & 0.198 & 0.208 & 0.227 & 0.193 & 0.203 & 0.217 & 0.191 & 0.200 & 0.214 \\
\hline
\end{tabular}


Table 4: Likelihood of default or extension for commercial real estate loans after 2012Q1

This table shows the estimated coefficients in the prediction model for estimating the likelihood of default or extension for commercial real estate loans after the crisis. The dependent variables of default (Panel A) and extension (Panel B) are based on whether the loan transitioned to default or extension after 2012Q1 (between 2012Q1 and 2015Q3). In Panel A, the dependent variable is a dummy variable indicating loans that transitioned into default (nonperforming). In Panel B, the dependent variable is a dummy variable indicating loans that transitioned into an extension. Fitted probabilities of securitization are computed from model (i) in Table 2 . High securitization probability is a dummy variable indicating that the probability of securitization is in the 75th percentile. Loan characteristics (amount, loan-to-value, occupancy) are in current values. Estimation sample is based on all loans originated after 2006. The sample consists of all CRE loans originated by large banks active in origination for CMBS market. The model is estimated with a logit specification. Robust standard errors in parentheses. ${ }^{* * *} \mathrm{p}<0.01,{ }^{*} \mathrm{p}<0.05,{ }^{*} \mathrm{p}<.1$.

Panel A:

Loan Default

\begin{tabular}{|c|c|c|c|c|c|c|c|c|c|}
\hline & (i) & (ii) & (iii) & (iv) & (v) & (vi) & (vii) & (viii) & (ix) \\
\hline Fixed-rate loan & $\begin{array}{c}-0.555^{* *} \\
(0.231)\end{array}$ & $\begin{array}{c}-0.552^{* * *} \\
(0.174)\end{array}$ & $\begin{array}{c}-0.479 * * * \\
(0.163)\end{array}$ & & & & & & \\
\hline Securitization probability & & & & $\begin{array}{c}-0.350 \\
(0.245)\end{array}$ & $\begin{array}{c}-0.363^{*} \\
(0.218)\end{array}$ & $\begin{array}{c}-0.307^{*} \\
(0.186)\end{array}$ & & & \\
\hline High securitization probability & & & & & & & $\begin{array}{l}-0.235 \\
(0.379)\end{array}$ & $\begin{array}{l}-0.351 \\
(0.416)\end{array}$ & $\begin{array}{l}-0.350 \\
(0.425)\end{array}$ \\
\hline Loan amount (log) & & $\begin{array}{l}-0.122 \\
(0.149)\end{array}$ & $\begin{array}{l}-0.156 \\
(0.152)\end{array}$ & & $\begin{array}{l}-0.081 \\
(0.158)\end{array}$ & $\begin{array}{c}-0.127 \\
(0.160)\end{array}$ & & $\begin{array}{l}-0.084 \\
(0.155)\end{array}$ & $\begin{array}{l}-0.131 \\
(0.158)\end{array}$ \\
\hline Loan-to-value & & $\begin{array}{c}1.764^{* * *} \\
(0.406)\end{array}$ & $\begin{array}{c}1.774^{* * *} \\
(0.368)\end{array}$ & & $\begin{array}{c}1.796^{* * *} \\
(0.419)\end{array}$ & $\begin{array}{c}1.791^{* * *} \\
(0.380)\end{array}$ & & $\begin{array}{c}1.810^{* * *} \\
(0.433)\end{array}$ & $\begin{array}{c}1.794^{* * *} \\
(0.387)\end{array}$ \\
\hline Occupancy rate & & $\begin{array}{c}-0.975^{* * *} \\
(0.127)\end{array}$ & $\begin{array}{c}-0.859^{* * *} \\
(0.214)\end{array}$ & & $\begin{array}{c}-0.990^{* * *} \\
(0.136)\end{array}$ & $\begin{array}{c}-0.855^{* * *} \\
(0.214)\end{array}$ & & $\begin{array}{c}-1.004^{* * *} \\
(0.156)\end{array}$ & $\begin{array}{c}-0.852^{* * *} \\
(0.220)\end{array}$ \\
\hline Constant & $\begin{array}{c}-4.464^{* * *} \\
(0.503)\end{array}$ & $\begin{array}{l}-2.840 \\
(2.778)\end{array}$ & $\begin{array}{l}-2.262 \\
(2.889)\end{array}$ & $\begin{array}{c}-4.483^{* * *} \\
(0.535)\end{array}$ & $\begin{array}{l}-3.501 \\
(2.890)\end{array}$ & $\begin{array}{l}-2.719 \\
(3.012)\end{array}$ & $\begin{array}{c}-4.561^{* * *} \\
(0.463)\end{array}$ & $\begin{array}{l}-3.515 \\
(2.797)\end{array}$ & $\begin{array}{l}-2.709 \\
(2.974)\end{array}$ \\
\hline Vintage fixed effects & yes & yes & yes & yes & yes & yes & yes & yes & yes \\
\hline Property type fixed effects & no & no & yes & no & no & yes & no & no & yes \\
\hline Bank fixed effects & no & no & yes & no & no & yes & no & no & yes \\
\hline Observations & 5179 & 5179 & 5179 & 5179 & 5179 & 5179 & 5179 & 5179 & 5179 \\
\hline Pseudo R-squared & 0.019 & 0.044 & 0.059 & 0.016 & 0.041 & 0.057 & 0.014 & 0.040 & 0.057 \\
\hline
\end{tabular}


Table 4 cont.: Likelihood of default or extension for commercial real estate loans after 2012Q1

Panel B:

\begin{tabular}{|c|c|c|c|c|c|c|c|c|c|}
\hline & \multicolumn{9}{|c|}{ Loan Extension } \\
\hline & (i) & (ii) & (iii) & (iv) & (v) & (vi) & (vii) & (viii) & (ix) \\
\hline Fixed-rate loan & $\begin{array}{c}-0.962^{* * *} \\
(0.224)\end{array}$ & $\begin{array}{c}-0.939^{* * * *} \\
(0.230)\end{array}$ & $\begin{array}{c}-1.027^{* * *} \\
(0.181)\end{array}$ & & & & & & \\
\hline Securitization probability & & & & $\begin{array}{c}-0.869^{* * *} \\
(0.268)\end{array}$ & $\begin{array}{c}-0.970^{* * *} \\
(0.213)\end{array}$ & $\begin{array}{c}-1.026^{* * * *} \\
(0.203)\end{array}$ & & & \\
\hline High securitization probability & & & & & & & $\begin{array}{c}-1.000^{* * *} \\
(0.137)\end{array}$ & $\begin{array}{c}-1.112^{* * *} \\
(0.139)\end{array}$ & $\begin{array}{c}-1.099^{* * *} \\
(0.153)\end{array}$ \\
\hline Loan amount (log) & & $\begin{array}{c}0.036 \\
(0.067)\end{array}$ & $\begin{array}{c}0.028 \\
(0.055)\end{array}$ & & $\begin{array}{l}0.122^{*} \\
(0.074)\end{array}$ & $\begin{array}{l}0.110^{*} \\
(0.064)\end{array}$ & & $\begin{array}{l}0.106 * * \\
(0.042)\end{array}$ & $\begin{array}{c}0.087^{* *} \\
(0.035)\end{array}$ \\
\hline Loan-to-value & & $\begin{array}{c}0.551 * * * \\
(0.124)\end{array}$ & $\begin{array}{c}0.640^{* * *} \\
(0.127)\end{array}$ & & $\begin{array}{c}0.639 * * * \\
(0.130)\end{array}$ & $\begin{array}{c}0.737 * * * \\
(0.134)\end{array}$ & & $\begin{array}{c}0.658^{* * *} \\
(0.154)\end{array}$ & $\begin{array}{c}0.695^{* * * *} \\
(0.140)\end{array}$ \\
\hline Occupancy rate & & $\begin{array}{l}-0.502 \\
(0.438)\end{array}$ & $\begin{array}{l}-0.409 \\
(0.385)\end{array}$ & & $\begin{array}{l}-0.552 \\
(0.418)\end{array}$ & $\begin{array}{l}-0.391 \\
(0.390)\end{array}$ & & $\begin{array}{l}-0.577 \\
(0.361)\end{array}$ & $\begin{array}{l}-0.397 \\
(0.364)\end{array}$ \\
\hline Constant & $\begin{array}{c}-0.252^{* *} \\
(0.115)\end{array}$ & $\begin{array}{l}-0.721 \\
(0.768)\end{array}$ & $\begin{array}{l}-0.203 \\
(0.571)\end{array}$ & $\begin{array}{l}-0.226^{*} \\
(0.117)\end{array}$ & $\begin{array}{c}-2.016^{* *} \\
(0.902)\end{array}$ & $\begin{array}{l}-1.418^{*} \\
(0.725)\end{array}$ & $\begin{array}{c}-0.388^{* * *} \\
(0.134)\end{array}$ & $\begin{array}{c}-1.932^{* * *} \\
(0.378)\end{array}$ & $\begin{array}{c}-1.213^{* * *} \\
(0.257)\end{array}$ \\
\hline Vintage fixed effects & yes & yes & yes & yes & yes & yes & yes & yes & yes \\
\hline Property type fixed effects & no & no & yes & no & no & yes & no & no & yes \\
\hline Bank fixed effects & no & no & yes & no & no & yes & no & no & yes \\
\hline Observations & 5179 & 5179 & 5179 & 5179 & 5179 & 5179 & 5179 & 5179 & 5179 \\
\hline Pseudo R-squared & 0.037 & 0.041 & 0.050 & 0.028 & 0.037 & 0.045 & 0.025 & 0.034 & 0.040 \\
\hline
\end{tabular}




\section{Table 5: Characteristics of CMBS-to-bank refinancing and traditional bank loans}

This table provides descriptive statistics for loans that were refinanced from CMBS to bank debt according to the matching algorithm. Other bank originations include all other income producing bank loans originated between 2007 and 2010. Both samples are limited to loans still in bank portfolios as of 2012:Q1. The average is reported for the continuous variables with the standard deviation in parentheses. Robust standard errors in parentheses. $* * * \mathrm{p}<0.01$, $* * \mathrm{p}<0.05, * \mathrm{p}<0.1$.

\begin{tabular}{lcc}
\hline \hline & & \\
Variable & CMBS/Bank Refis & All Other Bank Originations \\
Count & 373 & 22,055 \\
Percent ARM & $70.8 \%$ & $67.9 \%$ \\
Percent Originated by Banks Active in Both Markets & $73.5 \%$ & $67.6 \%$ \\
Percent Multifamily & $80.1 \%$ & $29.4 \%$ \\
Net Coupon Rate & $5.0 \%(1.8)$ & $4.4 \%(2.0)$ \\
Debt Yield 2012Q1 & $17.0 \%(10.9)$ & $18.9 \%(12.7)$ \\
Current Loan Amount (millions) & $\$ 3.92(7.04)$ & $\$ 5.24(13.76)$ \\
Origination Loan-to-Value & $57.6(16.7)$ & $59.5(21.3)$ \\
Current Loan-to-Value & $54.9(17.7)$ & $57.1(21.4)$ \\
Current Occupancy Rate & $87.3 \%(24.4)$ & $81.9 \%(28.4)$ \\
Percent in Default as of 2012Q1 & $2.34 \%$ & $2.97 \%$ \\
Percent Extended as of 2012Q1 & $0.82 \%$ & $2.08 \%$ \\
Percent in Default After 2012Q1 & $0.76 \%$ & $3.09 \%$ \\
Percent Extended After 2012Q1 & $12.6 \%$ & $22.7 \%$ \\
& & \\
\hline
\end{tabular}




\section{Table 6: Likelihood of default or extension for loans refinanced during CMBS shutdown}

This table compares likelihood of default and extension for traditional banks loans and bank loans that are indicated to be a refinancing of a prior CMBS loan. The sample is bank loans originated between 2007 and 2009 during the CMBS market shutdown. Loans are flagged as being in default or extension if they transitioned status by $2012 \mathrm{Q} 1$ (Panel A) or after 2012Q1 (Panel B). Loan characteristics (amount, loan-to-value, occupancy) are in current values. The model is estimated with a logit specification. Robust standard errors in parentheses. ${ }^{* * *} \mathrm{p}<0.01,{ }^{* *} \mathrm{p}<0.05, *$ $\mathrm{p}<0.1$.

Panel A: As of 2012Q1

\begin{tabular}{|c|c|c|c|c|c|c|}
\hline & \multicolumn{3}{|c|}{ Default } & \multicolumn{3}{|c|}{ Extension } \\
\hline & (i) & (ii) & (iii) & (i) & (ii) & (iii) \\
\hline CMBS refinance indicator & $\begin{array}{l}-0.198 \\
(0.387)\end{array}$ & $\begin{array}{c}-0.064 \\
(0.390)\end{array}$ & $\begin{array}{c}0.339 \\
(0.399)\end{array}$ & $\begin{array}{l}-0.847 \\
(0.582)\end{array}$ & $\begin{array}{c}-0.821 \\
(0.583)\end{array}$ & $\begin{array}{c}-0.691 \\
(0.587)\end{array}$ \\
\hline Loan amount $(\log )$ & & $\begin{array}{c}-0.106^{* *} \\
(0.051)\end{array}$ & $\begin{array}{c}-0.131^{* *} * \\
(0.052)\end{array}$ & & $\begin{array}{c}0.278^{* * *} \\
(0.044)\end{array}$ & $\begin{array}{c}0.273^{* * *} \\
(0.044)\end{array}$ \\
\hline Loan-to-value & & $\begin{array}{c}0.517^{* * *} \\
(0.043)\end{array}$ & $\begin{array}{c}0.474^{* * *} \\
(0.043)\end{array}$ & & $\begin{array}{c}0.0791^{*} \\
(0.047)\end{array}$ & $\begin{array}{c}0.092^{* *} \\
(0.045)\end{array}$ \\
\hline Occupancy rate & & $\begin{array}{c}-0.343^{* * *} \\
(0.030)\end{array}$ & $\begin{array}{c}-0.314^{* * *} \\
(0.032)\end{array}$ & & $\begin{array}{c}-0.149 * * * \\
(0.041)\end{array}$ & $\begin{array}{c}-0.162^{* * *} \\
(0.044)\end{array}$ \\
\hline Constant & $\begin{array}{c}-3.748^{* * *} \\
(0.098)\end{array}$ & $\begin{array}{c}-3.896^{* * *} \\
(0.102)\end{array}$ & $\begin{array}{c}-3.949^{* * *} \\
(0.147)\end{array}$ & $\begin{array}{c}-3.890^{* * *} \\
(0.093)\end{array}$ & $\begin{array}{c}-4.003^{* * *} \\
(0.096)\end{array}$ & $\begin{array}{c}-3.957^{* * *} * \\
(0.139)\end{array}$ \\
\hline Vintage fixed effects & yes & yes & yes & yes & yes & yes \\
\hline Property type fixed effects & no & no & yes & no & no & yes \\
\hline Bank fixed effects & no & no & yes & no & no & yes \\
\hline Observations & 16,528 & 16,528 & 16,528 & 21,593 & 21,593 & 22,593 \\
\hline Pseudo R-squared & 0.012 & 0.077 & 0.116 & 0.006 & 0.019 & 0.049 \\
\hline
\end{tabular}

Panel B: After 2012Q1

\begin{tabular}{|c|c|c|c|c|c|c|}
\hline & \multicolumn{3}{|c|}{ Default } & \multicolumn{3}{|c|}{ Extension } \\
\hline & (i) & (ii) & (iii) & (i) & (ii) & (iii) \\
\hline CMBS refinance indicator & $\begin{array}{c}-1.481^{* *} \\
(0.713)\end{array}$ & $\begin{array}{c}-1.423^{* *} \\
(0.713)\end{array}$ & $\begin{array}{l}-0.983 \\
(0.717)\end{array}$ & $\begin{array}{c}-0.673^{* * *} \\
(0.190)\end{array}$ & $\begin{array}{c}-0.655^{* * *} \\
(0.191)\end{array}$ & $\begin{array}{c}-0.176 \\
(0.204)\end{array}$ \\
\hline Loan amount (log) & & $\begin{array}{l}-0.012 \\
(0.056)\end{array}$ & $\begin{array}{l}-0.079 \\
(0.056)\end{array}$ & & $\begin{array}{c}0.221^{* * *} \\
(0.022)\end{array}$ & $\begin{array}{c}0.102^{* * *} \\
(0.025)\end{array}$ \\
\hline Loan-to-value & & $\begin{array}{c}0.376^{* * * *} \\
(0.051)\end{array}$ & $\begin{array}{c}0.324^{* * *} \\
(0.051)\end{array}$ & & $\begin{array}{c}0.145^{* * * *} \\
(0.023)\end{array}$ & $\begin{array}{c}0.127^{* * *} \\
(0.023)\end{array}$ \\
\hline Occupancy rate & & $\begin{array}{c}-0.154^{* * *} \\
(0.045)\end{array}$ & $\begin{array}{c}-0.101^{* *} \\
(0.046)\end{array}$ & & $\begin{array}{l}-0.010 \\
(0.025)\end{array}$ & $\begin{array}{c}0.023 \\
(0.027)\end{array}$ \\
\hline Constant & $\begin{array}{c}-3.650^{* * * *} \\
(0.111)\end{array}$ & $\begin{array}{c}-3.725^{* * *} \\
(0.114)\end{array}$ & $\begin{array}{c}-3.125^{* * *} \\
(0.159)\end{array}$ & $\begin{array}{c}-0.915^{* * *} \\
(0.039)\end{array}$ & $\begin{array}{c}-0.981^{* * *} \\
(0.040)\end{array}$ & $\begin{array}{c}-0.489^{* * *} \\
(0.067)\end{array}$ \\
\hline Vintage fixed effects & yes & yes & yes & yes & yes & yes \\
\hline Property type fixed effects & no & no & yes & no & no & yes \\
\hline Bank fixed effects & no & no & yes & no & no & yes \\
\hline Observations & 12,092 & 12,092 & 12,092 & 12,092 & 12,092 & 12,592 \\
\hline Pseudo R-squared & 0.005 & 0.027 & 0.066 & 0.051 & 0.070 & 0.228 \\
\hline
\end{tabular}

